\title{
Energy Use and Cost Analysis of Olive under Flat and Sloping Growing Conditions
}

\author{
Sakine Ozpinar ${ }^{1^{*}}$ \\ ${ }^{1}$ Agriculture Faculty, Canakkale Onsekiz Mart University, 17020, Canakkale, 17020. Turkey. \\ *Corresponding author: sozpinar@comu.edu.tr \\ ${ }^{1}$ https://orcid.org/0000-0002-4132-5931
}

Geliş Tarihi: 24.12.2019

Kabul Tarihi: 06.05.2020

\begin{abstract}
Olive is an important crop that grows under different cultivation systems of the western Turkey. Efficient use of energy and cost is an important step in terms of increasing the sustainability of olive cultivation. Energy and cost of olive farms analysed under traditional-flat/sloping and intensive-flat systems established on hilly or flat areas in a semiarid environment. Data of inputs and outputs collected in 165 farms through face to face questionnaires. Total energy consumed was 31098.2, 14293.3 and $7380.5 \mathrm{MJ} \mathrm{ha}^{-1}$ for intensive-flat, traditional-flat and sloping systems. Energy inputs of fertilizer was the highest for traditional and intensive flat by 12.93 and $8.95 \%$ of the total energy inputs, respectively. Highest net energy gain, ratio, productivity and lowest specific energy were estimated as $14332.8 \mathrm{MJ} \mathrm{ha}^{-1}, 1.46,0.93 \mathrm{~kg} \mathrm{MJ}^{-1}$ and $1.07 \mathrm{MJ} \mathrm{kg}^{-1}$, respectively, in intensive-flat system. Highest net return $\left(5256.5 € \mathrm{ha}^{-1}\right)$, a benefit to cost ratio (1.99) and productivity (1.66 kg $€^{-}$ ${ }^{1}$ ) was calculated for the same system. Therefore, the results can be very useful in evaluating the sustainability of olive cultivation in this part of the country possessing the characteristic of semiarid, and can also provide a useful guide in order to prioritize the steps for increasing energy efficiency and decreasing cost without worsening environmental conditions.
\end{abstract}

Keywords: Energy-cost analysis; land situation; olive.

\section{Düz ve Eğimli Arazi Koşullarında Zeytin Üretiminin Enerji ve Maliyet Analizi Öz}

Zeytin Türkiye'nin batı bölgelerindeki tarımsal üretim alanlarında yetişen önemli ürünlerden biridir. Zeytinin bu bölgede sürdürülebilir düzeyde yetişmesi için enerji kullanım etkinliği ve maliyet analiz gibi değerlendirmeler önem taşımaktadır. Bu amaçla gerekli olan veriler zeytin üretimi yapan 165 işletmeden anket yolu ile toplandı ve değerlendirildi. Elde edilen sonuçlara göre en yüksek toplam enerji girdisi $31098.2 \mathrm{MJ} \mathrm{ha}^{-1}$ ile yoğun tarımsal girdi ile üretimi gerçekleştiren düz arazi koşullarındaki modern üretim sistemi yer almış ve bunu sirasıyla $14293.3 \mathrm{MJ} \mathrm{ha}^{-1}$ ile geleneksel-düz ve $7380.5 \mathrm{MJ} \mathrm{ha}^{-1}$ ile geleneksel-eğimli arazilerdeki sistemler izlemiştir. Makina girdisi dikkate alınmaksızın, modern-düz (\%12.93) ve geleneksel-düz (\%8.95 9) üretim sistemlerinde kimyevi gübre toplam girdi içerisinde en yüksek paya sahip olduğu belirlenmiştir. En yüksek enerji kazanımı, oranı ve verimliliği ile en düşük spesifik enerji modern-düz sistemde sırasıyla $14332.8 \mathrm{MJ} \mathrm{ha}^{-1}$, $1.46,0.93 \mathrm{~kg} \mathrm{MJ}^{-1}$ ve $1.07 \mathrm{MJ} \mathrm{kg}^{-1}$ şeklinde hesaplanmıştır. Aynı zamanda bu sistemde en yüksek net kar $\left(5256.5 € \mathrm{ha}^{-1}\right)$ ve maliyet oranı (1.99) ile verimliliği $\left(1.66 \mathrm{~kg}^{-1}\right)$ 'de tespit edilmiştir. Bu nedenle, elde edilen sonuçlar yarı kurak iklim özelliği gösteren bölgede çevre koşullarına zarar vermeden zeytin üretiminin sürdürülebilir düzeyde devam edebileceğini ve ayrıca bu sonuçların bölge için yararlı bir veri kaynağı oluşturmada etkili olabileceği sonucuna varılmıştır.

Anahtar Kelimeler: Enerji-maliyet analizi; arazi durumu; zeytin.

\section{Introduction}

Olive (Olea europaea L.) is a tree that has lived for more than 500 years and adapted well to environmental conditions. It is known as a drought-resistant tree with a less than $200 \mathrm{~mm}$, but high olive yields can be obtained up to $600 \mathrm{~mm}$ in rainfed conditions. Olive was cultivated originally in the Mediterranean basin, and then, spread up to $600 \mathrm{~m}$ elevation such as southern Europe, northern Africa and the Iberian Peninsula. In world, olive grows more than 10 million hectares, of which $98 \%$ are located in ten-country of Mediterranean basin. Approximately, 19 million ton of olives are produced each year, $77 \%$ of which is harvested in this basin, including Spain, Italy and Greece. Other countries also have a significant amount of production (FAOSTAT, 2018); these are Portugal, Tunisia, Turkey, Morocco, Syria and Egypt. Turkey is fifth country of world having around 846 thousand hectares with 
about 180 million trees (TUIK, 2018). Olive cultivating is mostly concentrated in the southwest part of the country where coast of the Aegean, Mediterranean and southern Marmara Seas. Canakkale region is one of the areas in the southern Marmara, and represents 3.8\% of the cultivating area and $5.2 \%$ olive production (TUIK, 2018) at the national level. Olive is the most common crop in the region, but the cultivation is far from homogeneous due to the structural variables; these are tree age and density, cultivation system (rainfed, irrigated) as traditional or intensive, slope of hilly (mountains, flat) and production purpose (oil, table). In this environment, the traditional systems are typically located in mountainous on frequently found on sloping areas $(\geq 20 \%)$ and represent around $50 \%$ of the olive cultivation area with large cropping frames (TUIK, 2018). These systems are usually characterized with the lack of mechanization associated with low tree density, wide spacing between the row of trees, low yield (Table 1), wide and irregular shaped trees. Unlike the sloping systems, traditional-flat systems found on moderately sloping areas $(<20 \%)$ and occupies $35 \%$ of the olive cultivation area of the region. The traditional systems, especially for sloping areas, have high labour costs due to the lack of agricultural practices with non-mechanized, especially in harvesting (Bernardi et al., 2018). Therefore, such systems make a significant socio-economic contribution to the local community, especially in the harvest period, due to providing labour and income for several months with low labour productivity (Ozpinar, 2002; Rallo et al., 2013). The intensive cultivation systems are actively fertilized and irrigated, and highly mechanized, but they represent only a small percentage of olive cultivation area by $15 \%$ in the region. In agriculture, the energy use has increased recently further with growing the world food-demand because of increasing population and limiting arable areas. Therefore, a detailed energy analysis is needed for the cultivation systems with high energy consumption to maintain a more economical and sustainable cultivation. Nevertheless, inputs in olive cultivation may vary importantly depending on agricultural practices and techniques applied differently from one country to another or from one region to another, climate and cultural conditions and socio-economic factors, etc. Thus, it is important to know and manage the inputs of olive cultivation with the analysis of different agricultural practices. At the same time, economic benefit is also important to manage for sustainable and profitable cultivation systems in the study region. Several researchers have conducted studies on energy and economic analysis for olive cultivation in different countries and regions (Rafiee et al., 2010; Hemmati et al., 2013; Sánchez-Escobar et al., 2018; Kaltsas et al., 2007; Guzmán and Alonso, 2008; Cappelletti et al., 2014; Rajaeifar et al., 2014), but no studies on energy and even economic analysis have been conducted in this semiarid region located in western Turkey. The selection of this study for the region was basically, at both the regional and national level, due to the large rate from the olive cultivation under the rainfed-traditional on both sloping and flat, and the irrigation-intensive on flat. So, the objective of the study was to evaluate the input-output energy and economic analysis of the olive cultivation under intensive-flat, traditional-flat and traditional-sloping systems.

\section{Materials and Methods \\ Study framework}

The study was conducted in Canakkale region $\left(39^{\circ} 30^{\prime}-40^{\circ} 45^{\prime} \mathrm{N}\right.$ latitude and $25^{\circ} 35^{\prime}-27^{\circ} 45^{\prime} \mathrm{E}$ longitude) where surrounds the southern edge of Ida mountain with 1774 m elevation, western Turkey. So, the region has a few plains due to lands in the foothill of mountain as topological, while the altitude of the olive cultivation belt ranged from 8 to $388 \mathrm{~m}$. Olives are usually grown in the traditional way under rainfed conditions of the region (Table 1), but, in recent years, the modernization process of agriculture introduced irrigated cultivation by converting traditional olive cultivation to intensive, especially under flat areas since cultivation under rainfed conditions still represents around $90 \%$ of olive cultivation areas. The number of olive trees are around 5140 thousand (Table 2) in the region, many of which are inside Ida and Troy Natural Park boundaries, and they are nearly 3\% of the total cultivated olive trees in the country (around 175 million trees) (TUIK, 2018).

Data collection

The data were collected from the olive farms by a questionnaire with farmers face to face interviews during the year of 2017-2018. Data related to the year of olive cultivation are relevant to inputs and outputs in sub-regions (districts of the Canakkale region) (Table 1). 
Table 1. Agricultural practices and description of three olive cultivation systems according to average data of the questioned farms

Agricultural practices

Cultivation system

Slope

\section{Soil fertility}

Tree density (tree ha ${ }^{-1}$ )

Tree pattern

Olive yield $\left(\mathrm{kg} \mathrm{tree}^{-1}\right)$

Olive yield $\left(\mathrm{kg} \mathrm{ha}^{-1}\right)$

Oil yield $\left(1 \mathrm{~kg}^{-1}\right)$

Cultivar

Fruit quality

Economic life (years):

Average tree age range

Pruning yield $\left(\mathrm{kg} \mathrm{ha}^{-1}\right)$

Pruning (March-April)

Tillage and harrowing

Fertilizers

Irrigation per year

Plant protection

Weed control

Harvesting
Traditional-sloping

Traditional-rainfed

Mainly hilly, steep slope with more

than $20 \%$ of slope $(\geq 20 \%)$

Low

80-100 (Average of less than 100)

Irregular

$18.2 \pm 13.6$

$1820 \pm 506$

$0.17 \pm 0.09$

Ayvalık (Local variety)

Normal size and oil content 50

5-100 years

$584 \pm 127$

Pruning performs manually.

No mechanical operations

No-fertilizer.

Dry farming, rainfed conditions.

No application

No-herbicide. Grazing by sheep and goats

Hand picking using sticks and handheld combs.
Traditional-flat

Intensive-flat

Traditional-rainfed/irrigated

Moderate-steep slope/low to moderate with

and $20 \%$ of slope $(6-12 \% ; \leq 15)$

Medium

140-299 (Average 220)

Moderate regular

$25.2 \pm 18.4$

$5544 \pm 213$

$0.19 \pm 0.11$

Ayvalik (Local variety)

Normal size and oil content

$$
50
$$

5-100 years

$724 \pm 151$

Pruning performs manually.

Plough and harrowing by disc/tine harrow.

Manually and mechanically. Manure $(1000 \mathrm{~kg} \mathrm{ha}$

$\left.{ }^{1}\right)$, chemical $\left(\mathrm{N}: \mathrm{P}_{2} \mathrm{O}_{5}: \mathrm{K}_{2} \mathrm{O} ; 70: 9: 42 \mathrm{~kg} \mathrm{ha}^{-1}\right)$.

Dry farming. 3-5 times flood-irrigation $\left(440 \mathrm{~m}^{3}\right.$

$\mathrm{ha}^{-1}$ ) based on water availability.

1-2 time in year by sprayer [dimethoate (38\%)], [copper (20\%)].

Two times tillage and one time herbicide [

oxyfluorfen and glyphosate (41.5\%)].

Semi-mechanized by hand-held branch shakers.
Intensive-irrigated

\author{
Mainly flat, low to moderate with \\ Good \\ 250-300 (Average 275) \\ Regular \\ $32 \pm 21.9$ \\ $8800 \pm 615$ \\ $0.25 \pm 0.14$
}

Ayvalık (Local variety)

Normal size and oil content

50

\section{5-25 years}

$767 \pm 142$

Pruning performs mechanically.

Plough and harrowing by disc/tine harrow

Mechanically. Manure (1500 kg ha $\left.{ }^{-1}\right)$, chemical $\left(\mathrm{N}: \mathrm{P}_{2} \mathrm{O}_{5}: \mathrm{K}_{2} \mathrm{O} ; 110: 20: 60 \mathrm{~kg} \mathrm{ha}^{-1}\right)$.

Irrigation farming.4-6 times drip-irrigation $\left(550 \mathrm{~m}^{3} \mathrm{ha}^{-1}\right)$. Electric pumping.

3-4 time in year by sprayer [dimethoate (38\%)], [copper $(20 \%)$ ].

Two times tillage and herbicide [ oxyfluorfen and glyphosate $(41.5 \%)$ ].

Full-mechanized by tractor-mounted/self-

propelled branch shakers. 
Uncollected or incomplete data by questionnaire were obtained from current official statistical yearbooks, literature reports, the representatives of local management, the manufacture of material agencies, the expert knowledge as well as previous studies on olive. The size of required samples was determined by a method in order to collect data from the study region (Yamane, 1967). According to the sampling method, 165 olive farmers were randomly selected from farms which were already registered in the farmer registration system, and then data were divided to two groups of flat [110 farmers (5 traditional-flat and 5 intensive-flat) $x 11$ sub-regions)] and sloping [55 farmers (5 traditional-sloping) x 11 sub-regions)]. The output is only olive fruit yield and by-product including pruning residues.

\section{Input and output energy}

The inputs-outputs was considered, and then converted into the values of energy using the energy conversation coefficients (Pimentel et al., 1973; Mudahar and Hignett, 1987; Singh and Mittal, 1992; Kitani, 1999; Guzmán and Alonso, 2008; Rafiee et al., 2010; Bilandzija et al., 2012). The total energy per hectare of the olive cultivation systems was determined as the summation of energy from all the sources. Equation (1) was used to determine the total input energy per unit area in farm operations $\left(\mathrm{E}_{\mathrm{f}}\right)$ and machinery $\left(\mathrm{E}_{\mathrm{m}}\right)$ (Pimentel et al., 1973).

Table 2 . The number and productivity and non-productivity trees and pruning residues in the region

\begin{tabular}{cccccccrr}
\hline \multicolumn{2}{c}{$\begin{array}{c}\text { Number of trees }(\mathrm{x} 1000) \\
\text { non- }\end{array}$} & \multicolumn{3}{c}{ Pruning $\left(\text { ton year }^{-1}\right)^{\mathrm{a}}$} & \multicolumn{3}{c}{ Usable pruning $\left(\text { ton year }^{-1}\right)^{\mathrm{b}}$} \\
pro. & \multicolumn{1}{c}{ pro. } & \multicolumn{1}{c}{ Total } & \multicolumn{1}{c}{ pro. } & \multicolumn{1}{c}{ non-pro. } & \multicolumn{1}{c}{ Total } & \multicolumn{1}{c}{ pro. } & non-pro. & \multicolumn{1}{c}{ Total } \\
\hline Number 4626 & 514 & 5140 & 42003 & 2334 & 44337 & 29402 & 1634 & 31036 \\
$(\%)(90.00)^{\mathrm{c}}$ & $(10.00)$ & $(100.00)$ & $(94.74)$ & $(5.26)$ & $(100.00)$ & $(94.74)$ & $(5.26)$ & $(100.00)$ \\
\hline
\end{tabular}

${ }^{a}$ Weight of pruning residues on dry basis of productivity $\left(9.08 \mathrm{~kg}^{\mathrm{a}} \mathrm{rre}^{-1}\right)$ and non-productivity trees $\left(4.54 \mathrm{~kg}\right.$ tree $\mathrm{e}^{-}$

${ }^{1}$ ) per year. ${ }^{b}$ It assumed $0.70 \%$ of total pruning residues, while $0.30 \%$ is not collected.

Total input energy $=\mathrm{E}_{\mathrm{f}} \mathrm{E}_{\mathrm{m}}$

Where, $\mathrm{E}_{\mathrm{f}}$, input energy in farm operations $\left(\mathrm{MJ} \mathrm{ha}^{-1}\right) ; \mathrm{E}_{\mathrm{m}}$, machinery energy $\left(\mathrm{MJ} \mathrm{ha}^{-1}\right)$.

$E_{f}=\sum_{k=1}^{k=r}(\text { Phy }+ \text { Chem }+ \text { Bio })_{k}$

Where, Phy, Chem and Bio are physical, chemical and biological input energy in farm operations $\mathrm{k}^{\text {th }}$ $\left(\mathrm{MJ} \mathrm{ha}^{-1}\right)$; $\mathrm{k}$, farm operation $\mathrm{k}^{\text {th }}$. Physical energy was calculated as total input energy from human labour and mechanical power sources. $\mathrm{N}-\mathrm{P}_{2} \mathrm{O}_{5}-\mathrm{K}_{2} \mathrm{O}$ and crop protection products were considered as chemical input. Biological input includes seed and hormone which were no record data for those variables during questionnaire and were not taken into account. The machinery energy assumed as indirect energy for a piece of equipment which results from manufacturing (Mikkola and Ahokas, 2010).

$E_{m}=\sum_{m=1}^{m=t} \frac{(M+T+R)}{L}$

Where, $\mathrm{E}_{\mathrm{m}}$ is machinery energy $\left(\mathrm{MJ} \mathrm{ha}^{-1}\right) ; \mathrm{M}$ is manufacturing energy $\mathrm{m}^{\text {th }}(\mathrm{MJ})$; $\mathrm{T}$ is transportation energy $\mathrm{m}^{\text {th }}(\mathrm{MJ})$; $\mathrm{R}$ is repair energy $\mathrm{m}^{\text {th }}(\mathrm{MJ})$; $\mathrm{L}$ is the economic lifetime $\mathrm{m}^{\text {th }}(\mathrm{h})$ (Mikkola and Ahokas, 2010).

Total output energy $\left(\mathrm{MJ} \mathrm{ha}^{-1}\right)=\left(\right.$ Olive fruit yield $\left.\mathrm{x} \mathrm{E}_{\mathrm{eq}}\right)+\left(\right.$ Pruning yield $\left.\mathrm{x} \mathrm{E}_{\mathrm{eq}}\right)$

Energy ratio $($ dimensionless $)=\frac{\text { Output energy }\left(M J h a^{-1}\right)}{\text { Input energy }\left(M J h a^{-1}\right)}$

Energy productivity $\left(\mathrm{kg} \mathrm{MJ} J^{-1}\right)=\frac{\text { Olive fruit yield }\left(\mathrm{kg} \mathrm{ha}^{-1}\right)}{\text { Input energy }\left(M J \mathrm{ha}^{-1}\right)}$

Specific energy $\left(M J \mathrm{~kg}^{-1}\right)=\frac{\text { Input energy }\left(M J h a^{-1}\right)}{\text { Olive fruityield }\left(\mathrm{kg} \mathrm{ha}^{-1}\right)}$ 
Net energy gain $\left(\mathrm{MJ} \quad \mathrm{ha}^{-1}\right) \quad=$ Output energy $\left(\mathrm{MJ} \mathrm{ha}^{-1}\right)$-Input energy $\left(\mathrm{MJ} \mathrm{ha}^{-1}\right)$ (8)

The purpose of analysis for economic was to compare the probability of the olive cultivation systems. For this purpose, data related to input-output and their economic coefficients were collected through the questionnaire, and then they were converted into economic information (Rajaeifar et al., 2014). Prices and wages are referred to the cultivation year of 2017-2018. All data were converted from Turkish Lira (TL) to Euro $(€)$ using exchange rate of respective 2018-year.

Total cultivation value $\left(€ h a^{-1}\right)=$ Olive yield $\left(\mathrm{kg} \mathrm{ha}^{-1}\right)$ x Olive price $\left(€ \mathrm{~kg}^{-1}\right)$

Gross return $\left(€ h a^{-1}\right)=$ Total cultivation value $\left(€ h a^{-1}\right)$-Variable cultivation costs $\left(€ h a^{-1}\right)$

Net return $\left(€ h a^{-1}\right)=$ Total cultivation value $\left(€ \mathrm{ha}^{-1}\right)$-Total cultivation costs $\left(€ h \mathrm{~h}^{-1}\right)$

$\frac{\text { Benefit }}{\text { cost }}$ ratio $\left(M J \mathrm{~kg}^{-1}\right)=\frac{\text { Total cultivation value }\left(€ h a^{-1}\right)}{\text { Total cultivation costs }\left(€ h a^{-1}\right)}$
Productivity $\left(k g €^{-1}\right)=\frac{\text { Olive yield }\left(\mathrm{kg} h a^{-1}\right)}{\text { Total cultivation costs }\left(€ h a^{-1}\right)}$

\section{Results and Discussion}

Agricultural structure of olive cultivation systems at the regional level

According to the results of the questionnaire analysis, the yield is generally below the olive yields in the Mediterranean basin (Table 1). However, yield variation is depending on periodicity as influenced by typical "off" and "on" years and variety, while sometimes reached 70-75 kg tree ${ }^{-1}$ in productivity year and sometimes decreased $30-35 \mathrm{~kg}^{-1} \mathrm{ee}^{-1}$ under low fertile sloping soils (Table 1). The farmers of the studied region presented that they generally prefer high yield per tree instead of per unit area because of old trees with low density and large tops. However, mechanical harvesting of such trees is difficult or even impossible; therefore, the harvest is still performed manually. Most of the agricultural work is done by family members and this is more than $52 \%$ of labour, the rest is provided by the members of the hiring foreign immigrants, especially at the harvesting season. This high family labour opportunity helps the current sustainability of traditional systems, as long as these farmers are willing and able to work in their olive cultivating areas. Nevertheless, in the studied region, the 7938 of total farmers occupied with olive cultivation, corresponds to $36.2 \%$ and $1.98 \%$ of the total farmers at the regional and the national level, respectively (TUIK, 2018). Farmers were occupied with olive cultivation since centuries due to the fact that it has a stratgic importance for both economy and social of the region. In addition to the economic and social significance, the olive cultivation has a high potential role for affecting the environment such as biodiversity and soil erosion. According to the questionnaire data, the majority of farmers were male, up to $76 \%$ and the average age level 44.8 years old, but $40 \%$ of farmers is 65 or older who still can participate in cultivating. On the other hand, the lack of social and cultural facilities also increases leaving, especially young people over 15 year of age who are moving away from the region. Additionally, it was noted that the demographic characteristics of the study region, the declining population and labour resources contribute to increase the olive cultivation energy inputs (Ozpinar, 2002). Human labour, assuming male, used commonly in production of olive and it was higher in sloping growing areas than in flats (Table 3) while seasonal labours are often employed during olive harvest period from September to February despite the existence of family-based agricultural employment, of which approximately $52 \%$. Considering sloping trees, all practices were almost done by hand, pruning, harvesting, transporting, etc., due practically to mechanical practices in sloping can be dangerous for tractor drivers in the studied area (Table 1). Traditional cultivation system on sloping and flat areas consumes more labour inputs throughout the growing season compared with intensive cultivation system, but sometimes it is conducted combination with hand-held shakers powered by electric or fuel oil using by human labour and selfpropelled harvester. Using both hand-held shaker or self-propelled harvester reduced the cultivation costs and also input energy and also improve the quality of the olives and subsequently of the oil. The hand-held shaker also increased the work productivity with doubled rate compared with harvesting by hand using comb and stick (Table 3). When harvesting is done by hand, labour input at olive cost is around $70 \%$ of annual expenses, but when mechanical methods are used, this rate drops to around $50 \%$ 
(Tombesi et al., 2002; Bernardi et al., 2018) despite harvesting has a high weight on olive total cultivation costs, followed by pruning could varies between 15 and 20\%. Tombesi et al. (2002).

Estimation of energy flow and comparative analysis for the olive cultivation system

The highest share of output energy found for olive fruit energy with $73.32 \%$ compared to the pruning energy with $26.68 \%$ in intensive-flat cultivation system (Table 3). In contrast, the pruning energy was higher than olive fruit energy in traditional-sloping and flat systems by $91.52 \%$ and $54.11 \%$, respectively. Both systems were provided the greatest amount of pruning energy compared with fruit energy, since the very ancient olive trees and their canopy volume (height and width) allows the obtaining a higher quantity of pruning residues. Total output energy in the intensive-flat system is higher than in both of them due to higher yield of olive fruit with $8800 \mathrm{~kg} \mathrm{ha}^{-1}$ and the highest amount of pruning residues with $767 \mathrm{~kg} \mathrm{ha}^{-1}$ (Table 1) since the high density of the olive tree per unit area allows higher plant residues. In contrast, olive fruit and pruning residues yield were lower in both traditional systems and recorded as 724 and $5544 \mathrm{~kg} \mathrm{ha}^{-1}$ in flat, and 584 and $1820 \mathrm{~kg} \mathrm{ha}^{-1}$ in sloping, respectively (Table 1). Therefore, the traditional systems should improve their productivity by optimizing the use of farmyard manure and cover crop such as legumes during their growing period since certain good practices are not yet widely used by farmers. Similar results were obtained by others in different countries (e.g., Cappelletti et al., 2014; Rajaeifar et al., 2014; Romero-Gámez et al., 2017)) who concluded that olive tree systems with high density return the highest amount of energy due to high amount pruning residues. In terms of pruning residues by one hectare of surface on average 275 tree $\mathrm{ha}^{-1}$ (Table 1), the higher amount of output energy would be obtained from the intensive cultivation system with $45431.0 \mathrm{MJ} \mathrm{ha}^{-1}$ (Table 3), followed by traditional-flat and sloping with 19732.0 and 10499.0 $\mathrm{MJ} \mathrm{ha}^{-1}$, respectively. There were differences between references and the results obtained from the study which may be the results of different climate conditions, and pruning methods. Comparing the results obtained by Bilandzija et al. (2012) who collected pruned residues in the olive trees $2524 \mathrm{~kg} \mathrm{ha}^{-1}$ which is higher than in intensive-flat, traditional-flat and sloping systems (Table 1).

Table 3. Energy inputs and outputs in olive cultivation systems.

Input/output

\begin{tabular}{|c|c|}
\hline Traditional-sloping & Traditional-flat \\
\hline
\end{tabular}

A. Inputs

\begin{tabular}{lcccccc} 
Human labour & 6786.00 & 91.94 & 1145.00 & 8.01 & 964.32 & 3.09 \\
Diesel fuel & 191.20 & 2.59 & 1840.30 & 12.88 & 2876.47 & 9.22 \\
Machinery & 403.30 & 5.46 & 8238.00 & 57.64 & 22322.40 & 71.55 \\
Chemical fertilizer & - & - & 1848.00 & 12.93 & 2791.00 & 8.95 \\
$\quad$ Nitrogen $(\mathrm{N})$ & - & - & 1562.00 & $84.52^{\mathrm{b}}$ & 2343.00 & $83.95^{\mathrm{b}}$ \\
$\quad$ Phosphorus $\left(\mathrm{P}_{2} \mathrm{O}_{5}\right)$ & - & - & 121.80 & $6.59^{\mathrm{b}}$ & 174.00 & $6.23^{\mathrm{b}}$ \\
$\quad$ Potassium $\left(\mathrm{K}_{2} \mathrm{O}\right)$ & - & - & 164.40 & $8.90^{\mathrm{b}}$ & 274.00 & $9.82^{\mathrm{b}}$ \\
Farmyard manure & - & - & 1192.00 & 8.34 & 596.00 & 1.91 \\
Plant protection products & - & - & 30.00 & 0.21 & 30.00 & 0.10 \\
Water for irrigation & - & - & - & - & 918.00 & 2.94 \\
Electricity & - & - & - & - & 600.00 & 1.92 \\
Total energy input & 7380.50 & 100.00 & 14293.30 & 100.00 & 31098.19 & 100.00 \\
Mutputs (through the cultivation period) & & & & & \\
Olive fruit (main product) & 890.46 & 8.48 & 9055.79 & 45.89 & 33308.98 & 73.32 \\
Pruning (by product) & 9608.34 & 91.52 & 10675.93 & 54.11 & 12121.62 & 26.68 \\
Total energy output & 10499.00 & 100.00 & 19732.00 & 100.00 & 45431.00 & 100.00 \\
\hline
\end{tabular}

${ }^{a}$ Percentage from total input energy. ${ }^{b}$ Percentage from input energy of total chemical fertilizer.

Farmers in the studied region have no general experience in preparation and use of pruning residues converting energy. Therefore, there is a need for introducing new technologies in the use of 
this type of residues to produce energy for consumption at the regional level, which contributes to environmental protection. It is clear that among the three olive cultivation systems, the traditionalsloping is the one that requires less amounts of input energy per hectare under rainfed conditions with large planting frames and steep slopes when compared to the other systems. Although some practices have been done by hand-held tools such as scissors and saws, the system is still characterized by very low productivity. Instead, the intensive-flat system involves a higher use of energy and material sources (31098.2 $\left.\mathrm{MJ} \mathrm{ha}^{-1}\right)$ than traditional-flat $\left(14293.3 \mathrm{MJ} \mathrm{ha}^{-1}\right)$ and sloping $\left(7380.5 \mathrm{MJ} \mathrm{ha}^{-1}\right)$. The higher energy use in intensive is explained by a larger number of practices and the increased mechanization of cultivation practices (Table 1). In fact, in this system, up to $71.55 \%$ of the energy consumption is due to the use of machinery. In contrast, in traditional-sloping, human energy which has the main contribution to input energy constitutes the highest share of $91.94 \%$ of total input energy, due to high human labour requirements, especially at the harvest, pruning, and also for transporting. In this system, tree growing conditions such as inaccessibility of routes and excessive tree height and wide slow down tree maintenance is increasing the required hours of labour, but the use of mechanization allows the survival of this type of olive growing by reducing work energy (Bernardi et al., 2018). Several researchers have shown that human labour is the most important energy consumption sources in agricultural systems (e.g., Rafiee et al., 2010; Hemmati et al., 2013). Rafiee et al. (2010) reported that the highest use of human labour was recorded in the operations of the harvesting (56\%) and pruning (23\%), while Bernardi et al. (2018) declared the similar results with $50 \%$ rate.

Input energy in fertilizers recorded higher in traditional-flat and intensive-flat by $12.93 \%$ and $8.95 \%$, respectively in total energy, especially nitrogen fertilizer. In traditional and intensive olive cultivation systems on flat areas, excessive use of fertilizers usually occurs from lack of knowledge by farmers about their optimal dosage. Farmers usually were not aware of the actual amount of fertilizers to be applied to the olive. Farmers often believe that increasing the amount of fertilizers will increase the fruit yield due to no-soil testing to determine the more accurate level of fertilizers and decrease their use. Similarly, Rajaeifar et al. (2014) reported that nitrogen fertilizer had the highest rate from total energy inputs. Cappelleti et al. (2014) also obtained that the production and application fertilizer is the most production factors, which require a considerable amount of energy and constitutes $72 \%$ of the total input energy requirement for traditional centenary olive system. Romero-Gámez et al. (2017) come to a similar conclusion with regard to using of fertilizers. They also suggested that fertilization was the first priority to optimize olive growing among all other inputs. Kaltsas et al. (2007) also found that fertilizer application was one of the highest energy inputs in either traditional or intensive olive cultivation systems. The use of large amounts of farmyard manure as well as cultivation of cover crops can be considered in order to supply the required consumption of nitrogen. The application of farmyard manure, in the region, was lower in olive cultivation than in annual crops such as wheat, maize, sunflower, etc.; therefore, there is need new cultivation practices for improvement. Sheep and goat manure (generally include $0.8 \% \mathrm{~N}, 0.23 \% \mathrm{P}_{2} \mathrm{O}_{5}$ and $0.67 \% \mathrm{~K}_{2} \mathrm{O}$ ) with high potential availability in the study region (Özpınar, 2018) are suitable substitutes in order to reduce the high amount of nitrogen application, and using legumes as cover crops absorbing atmospheric nitrogen during winter season between tree rows (Kaltsas et al., 2007). The energy input of farmyard manure application was significantly higher in the traditional-flat system than in the study, while Rajaeifar et al. (2014) found $916 \mathrm{MJ} \mathrm{ha}^{-1}$ with the share of $4.80 \%$ for olive in Iran. The high energy consumption for farmyard in the study according to the earlier results may be attributed to transportation distance (Table 1). The traditional-sloping system requires the lowest machinery input due to lack of machinery traffic with only hand-held tools for pruning and harvesting, and their low weight by $403.3 \mathrm{MJ}^{-1}{ }^{-1}$ with $5.46 \%$, followed by traditional-flat by $8238.0 \mathrm{MJ} \mathrm{ha}^{-1}$ with $57.64 \%$. This results show less tendency to mechanized cultivating operation in larger olive growing areas which are mainly located in the sloping and foothills of the area. Under intensive-flat which used machinery in almost all cultural practices from tillage to olive transportation, the highest input was found with machinery by $71.55 \%$ due to high number of field traffic and weight self-propelled harvester followed by diesel fuel and fertilizers by $9.22 \%$ and $8.95 \%$, respectively. The consumption of diesel used for cultivation practices in the high density tree of systems results as being higher than that of the traditional system, since soil cultivation, weed control and harvesting are the cultural practices that require more fuel (Cappelletti et al., 2014). 
In the study, fuel was consumed for weed control which is conducted by harrowing in the traditionalflat system, mowing, and the application of herbicides in the intensive-flat system (Table 1). The intensive-flat system is one that require higher amounts of fuel, since it is a fully mechanized and; therefore, requires a higher fuel for machinery. This is due to the fact that the system is mostly mechanized allow to perform harvesting procedures more efficiently. It has also been reported that the energy input of fertilizers has the highest share of the total energy input in agricultural production (Hemmati et al., 2013; Cappelletti et al., 2014) in regardless of machinery. In a study conducted by Kaltsas et al. (2007) who studied the energy budged in conventional and organic olive cultivation systems in Greece, and they found that irrigation and fertilizer application had the highest amount of total energy consumption in both systems. They also reported that irrigation and fertilizer application energy demand accounted for approximately $21 \%$ and $12 \%$ of the total energy consumption, respectively, in conventional Greece olive growing areas. Guzmán and Alonso (2008) reported that irrigation represented the greatest input energy in olive cultivation. Romero-Gámez et al. (2017) recorded that intensive and super-intensive olive growing systems are responsible for high environmental impacts due to the electricity consumed during cultivation period; for example, for irrigation. The electricity energy in the studied region was only used for pump in order to water from water wells or source. It had the share of about $2.94 \%$ from total input energy for intensive-flat system and was lower than the study concluded by Rajaeifar et al. (2014) with 4\%. On the other hand, Romero-Gámez et al. (2017) reported that the deficit irrigation in olive growing did not reduce the production and quality of the harvesting.

Energy ratio was determined as $1.46,1.38$ and 1.42 for intensive-flat, traditional-flat and traditional-sloping systems, respectively (Table 4). This indicating that energy using in olive cultivation in the studied region is efficient, i.e. energy production was higher than energy consumption for three-type of olive systems. Lower energy ratio in both traditional systems is highly attributed to the lower olive fruit yield and then less output energy compared to the intensive-flat system.

Table 4. Energy indices in the questionnaire farms for three olive cultivation systems.

\begin{tabular}{lccccccc}
\hline \multirow{2}{*}{ Energy pattern } & \multicolumn{3}{c}{ Traditional-sloping } & \multicolumn{2}{c}{ Traditional-flat } & \multicolumn{2}{c}{ Intensive-flat } \\
\cline { 2 - 8 } & Unit & Quantity & $(\%)$ & Quantity & $(\%)$ & Quantity & $(\%)$ \\
\hline Energy ratio & - & 1.42 & & 1.38 & & 1.46 & \\
Energy productivity & $\mathrm{kg} \mathrm{MJ}^{-1}$ & 0.75 & & 0.92 & & 0.93 & \\
Specific energy & $\mathrm{MJ} \mathrm{kg}^{-1}$ & 1.34 & & 1.09 & & 1.07 & \\
Net energy gain & $\mathrm{MJ} \mathrm{ha}^{-1}$ & 3118.48 & & 5438.30 & & 14332.81 & \\
Direct energy & $\mathrm{MJ} \mathrm{ha}^{-1}$ & 6977.20 & 94.53 & 2984.72 & 20.04 & 5358.32 & 17.23 \\
Indirect energy & $\mathrm{MJ} \mathrm{ha}^{-1}$ & 403.30 & 5.46 & 11308.20 & 75.92 & 25739.40 & 82.77 \\
Renewable energy & $\mathrm{MJ} \mathrm{ha}^{-1}$ & 6786.00 & 91.94 & 2336.72 & 15.69 & 2478.32 & 7.97 \\
Non-renewable energy & $\mathrm{MJ} \mathrm{ha}^{-1}$ & 594.50 & 8.05 & 11956.20 & 80.28 & 28619.40 & 92.03 \\
Total energy input & $\mathrm{MJ} \mathrm{ha}^{-1}$ & 7381.00 & & 14894.00 & & 31098.00 & \\
\hline
\end{tabular}

Kaltsas et al. (2007) reported the energy ratio of conventional olive growing in Thasos island of Greece to be 3.02, which is higher than those of the study. Rajaeifar et al. (2014) defined higher energy ratio of 3.02 for olive cultivation in Iran. However, it was lower by 1.16 for apple (Rafiee et al., 2010). Hemmati et al. (2013) concluded that energy ratio was higher for flat and sloping areas by 1.60 and 1.47 , respectively. Energy productivity was $0.93 \mathrm{~kg} \mathrm{MJ}^{-1}$ for intensive-flat system, followed by traditional-flat and traditional-sloping systems by 0.92 and $0.75 \mathrm{~kg} \mathrm{MJ}^{-1}$, respectively (Table 4). Kaltsas et al. (2007) and Rajaeifar et al. (2014) recorded lower energy productivity with 0.07 and 0.08 $\mathrm{kg} \mathrm{MJ}^{-1}$ in Thasos, Greece for conventional olive cultivation system and in Guilan province of Iran, respectively. The specific energy for traditional-slope, traditional-flat and intensive-flat system was calculated as $1.34,1.09$ and $1.07 \mathrm{MJ} \mathrm{kg}^{-1}$, respectively. In fact, it should be noted that the energy ratio, productivity and specific energy are based on the spent energy for fuel, fertilizer, machinery, human labour, etc. Net energy gain is shown the value of produced or consumed energy in a cultivation 
system and it has been produced higher in both traditional and intensive systems on flat areas compared with traditional-sloping. Higher net energy gains and energy ratio and energy productivity of intensive system indicate that excessive use of inputs to produce higher level of yield. Cappelleti et al. (2014) concluded that intensive olive cultivation systems provide the most energy return due to the amounts of pruning residues are generated in the system. In contrast, Guzmán and Alonso (2008) studied that organic olive systems have higher energy efficiency in comparison with the conventional for olive in Spain. Traditional-sloping and intensive-flat were almost similar in use of direct energy, but both systems increased direct energy compared with traditional-flat. Indirect energy was the highest in intensive-flat due to the highest machinery and fertilizer inputs, while it was the lowest in traditional-sloping because there are no inputs such as fertilizers or plant protection products, etc. Thus the rate of renewable energy in traditional-sloping by $91.94 \%$ was more than traditional-flat by $15.69 \%$, while it was the lowest proportion was in the intensive-flat by $7.97 \%$ due to using more human labour in the traditional-sloping. Non-renewable energy was obtained with highest rate by $92.03 \%$ in intensive-flat due to using more machinery, and also fertilizers and pesticides, this also refer to the consumption of electricity for irrigation (Table 4). Considering traditional and intensive on flat areas, indirect and renewable energy were higher agreement with similar studies on olive (Rajaeifar et al., 2014).

\section{Economic analysis of the olive cultivation systems}

The gross value of cultivation was found to be $10560.0,6652.8$ and $2184.0 € \mathrm{ha}^{-1}$ per year for intensive-flat, traditional-flat and -sloping, respectively (Table 5). Annual total cost of olive cultivation systems was estimated as $5303.5 €$ per hectare for intensive-flat, followed by traditionalflat and sloping by 3478.4 and $1281.8 €$, respectively, while others (e.g., Sánchez-Escobar et al., 2018) has been come to similar results. The total cost is severely affected by the degree of mechanization of the olive system; for example, due to the complete mechanization of tillage and harvesting operations in the intensive-flat. The higher variable costs in intensive-flat system are revealed to the use of higher variable inputs such as machinery, fuel, repair-maintenance, fertilizer, crop protection product, water and electricity (Table 1).

Table 5. Economic analysis and relationship between economic performance of cultivation systems

\begin{tabular}{|c|c|c|c|c|}
\hline Cost and return components ${ }^{\mathrm{a}}$ & Unit & Traditional-sloping & Traditional-flat & Intensive-flat \\
\hline Yield & $\mathrm{kg} \mathrm{ha}^{-1}$ & 1820 & 5544 & 8800 \\
\hline Sale price & $€ \mathrm{~kg}^{-1}$ & 1.20 & 1.20 & 1.20 \\
\hline Gross value of cultivation & $€ \mathrm{ha}^{-1}$ & 2184.0 & 6652.8 & 10560.0 \\
\hline Variable costs & $€ \mathrm{ha}^{-1}$ & $1113.8(86.89)^{\mathrm{b}}$ & $2948.7(84.77)$ & $4364.8(82.30)$ \\
\hline Fixed cultivation costs & $€ \mathrm{ha}^{-1}$ & $168.0(13.11)^{\mathrm{b}}$ & $529.7(15.23)$ & $938.7(17.70)$ \\
\hline Total cultivation costs & $€ \mathrm{ha}^{-1}$ & 1281.8 & 3478.4 & 5303.5 \\
\hline Total cost of olive fruit & $€ \mathrm{~kg}^{-1}$ & 0.59 & 0.52 & 0.50 \\
\hline Gross return & $€ \mathrm{ha}^{-1}$ & 1070.2 & 3704.1 & 6195.2 \\
\hline Net return & $€ \mathrm{ha}^{-1}$ & 902.16 & 3174.4 & 5256.5 \\
\hline Benefit/cost ratio & - & 1.70 & 1.91 & 1.99 \\
\hline Productivity (only main product) & $\mathrm{kg} €^{-1}$ & 1.42 & 1.59 & 1.66 \\
\hline $\begin{array}{l}\text { Energy obtained by each euro spent } \\
\text { on cultivation }\end{array}$ & $\mathrm{MJ} €^{-1}$ & 5.7 & 8.2 & 8.6 \\
\hline $\begin{array}{l}\text { Euros generated (net return) by each } \\
\text { unit of input energy }\end{array}$ & $€^{-1} \mathrm{MJ}$ & 0.12 & 0.17 & 0.27 \\
\hline
\end{tabular}

${ }^{\mathrm{a}}$ Converted Turkish Lira (TL) to Euro $(€), 1 € 6.67$ TL. ${ }^{\mathrm{b}}$ Percentage of total cost.

This has been followed by traditional-flat due to less variable inputs in comparable to intensive-flat system, and then the traditional-sloping having the lowest variable inputs. The variable and fixed costs had the share of $82.30 \%$ and $17.70 \%$ from total cost of cultivation, respectively, in intensive-flat. The corresponding values for traditional-flat and sloping are $84.77 \%$ and $15.23 \%$, and $86.89 \%$ and $13.11 \%$, respectively. Several researchers reported that the ratio of variable costs was higher than that of fixed costs in agricultural cultivation systems (e.g., Hemmati et al., 2013; Rajaeifar et al., 2014). Similarly, Sánchez-Escobar et al. (2018) concluded that intensive cultivation systems increased the total costs compared with the traditional ones because of high harvesting cost. It was 
note that both traditional systems are heavily influenced by labour-intensive operations; for example, the cost of harvesting and pruning operations are $93.00 \%$ and $61.00 \%$ of total costs in traditionalsloping and flat, respectively, while this rate was lower with $44.00 \%$ in intensive-flat. However, Sánchez-Escobar et al. (2018) concluded that intensive olive cultivation systems has been consumed more cost for harvesting by $65 \%$, while the traditional ones was lower by $58.00 \%$. Based on the results, the benefit to cost ratio was found to be $1.99,1.91$ and 1.70 for intensive-flat, traditional-flat and sloping, respectively. The study results were agreement with similar studies on olive (SánchezEscobar et al., 2018) who concluded that the intensive systems increased this factor varying between $1.5-1.59$ respect to traditional by 1.29 . These findings were also consistent with the results reported by others such as 2.11 for olive oil (Rajaeifar et al., 2014) and 1.52 and 1.35 for olive growing under flat and sloping land conditions, respectively (Hemmati et al., 2013). Finally, three systems reached a positive net return per hectare in year of study; nevertheless, intensive-flat was six and two times more profitable than traditional-sloping and flat, respectively. The value of net return and benefit to cost ratio indicated that olive cultivation is more economical in intensive-flat system. The economical results of this study indicate that more activities are required to improve the efficiency of energy input in olive cultivation and to use environmentally friendly agricultural practices. Due to high olive cultivation costs in the region as in the country, olive product prices for sale, especially olive oil, should be encouraged for sustainability in either domestic or foreign market.

\section{Conclusions}

Olive cultivation is one of the agricultural activities in Canakkale region of Turkey that has important economic, social and environmental impacts although it is far from homogeneous due to different types of olive cultivation systems. Traditional-sloping and flat cultivation are main systems, although intensive-flat is increasing steadily every year in the region. The total input energy was the highest in the intensive-flat system, followed by traditional-flat and sloping systems, while labour is the most efficiently used input for olive cultivation system on flat ones. Output energy (with byproduct residues allocation) was calculated higher in intensive-flat than other two systems. In addition, fruit and pruning yields affecting energy output when higher fruit yield per unit area obtained with the use of more inputs in intensive-flat, followed by traditional-flat and -sloping. The most used input in the olive was nitrogen fertilizer with $83.95 \%$, followed by potassium fertilizer $(9.82 \%)$ for both flat systems due to excessive use of fertilizer, except machinery energy, and human labour (91.94\%) for traditional-sloping. Among energy sources, machinery energy was highest in both flat systems. Energy ratio and productivity were calculated as $1.46,1.42$ and 1.38 , and $0.93,0.92$ and 0.75 for intensiveflat, traditional-flat and traditional-sloping systems, respectively. The benefit to cost ratio and net returns of the intensive-flat were found to be higher than that of traditional-flat and sloping. As a result, it is seen that harvesting is a critical aspect of traditional-sloping system done by hand or handheld combs and shakers, which increased the labour input energy. In regard to the mechanization efficiency of traditional olive cultivation system, traditional-flat olive cultivation farms are favored by mechanization advantages in relation to the conditions faced by flat areas. Alternative and suitable mechanization applications are needed in order to reduce the harvest labour input energy. Further, the amount of non-renewable energy in both flat systems was rather high, $80.28 \%$ and $92.03 \%$ in traditional and intensive, respectively. It needs to reduce fertilizer and crop protection product, and use these more efficiently and promising organic fertilizer and pest control, and industrial energy resources replaced with biological ones based on natural farming systems. The use of cover crops or farmyard manure in order to supply the required nitrogen may be a useful way in order to keep the soil fertility in olive cultivation. In addition, the results show that in the region, by reducing the use of diesel fuel, fertilizer and crop protection product inputs are significant to conserve energy and decreasing the environmental risk problem. On the other hand, machinery is extensively used for soil tillage, weed control, spraying, harvesting, pruning and transportation, etc., in cultivation period leading to a high level of required diesel fuel energy, especially in intensive systems. Furthermore, if potential energy from pruning residues accounted, it can be calculated that this sector of agriculture contributes to the energy consumption in agriculture as well as all other sectors. Consequently, converting the pruning residues into energy can increase the value of waste materials and contribute the environmental protection. 


\section{References}

Bernardi, B., Falcone, G., Stillitano, T., Benalia, S., Strano, Bacenetti, A.J., De Luca, A.I., 2018. Harvesting system sustainability in Mediterranean olive cultivation. Sci. of the Total Envi. 625, 1446-1458.

Bilandzija, N., Voca, N., Kricka, T., Matin, A., Jurisic, V., 2012. Energy potential of fruit tree pruned biomass in Croatia. Spanish J of Agri. Res. 10, 292-298.

Cappelletti, G.M., Ioppolo, G., Nicoletti, G.M., Russo, C., 2014. Energy requirement of extra virgin olive oil production. Sustainability. 6, 4966-4974.

FAOSTAT, 2018. The Food and Agriculture Organization (FAO) of the United Nations (UN) Statistical Database. http://www.faostat3.fao.org; 2019 (accessed 15 September 2019).

Guzmán, G.I., Alonso, A.M., 2008. A comparison of energy use in conventional and organic olive oil production in Spanish. Agricultural Systems. 98, 167-176.

Hemmati, A., Tabatabaeefar, A., Rajabipour, A., 2013. Comparison of energy flow and economic performance between flat land and sloping land olive orchards. Energy. 61, 472-478.

Kaltsas, A.M., Mamolos, A.P., Tsatsarelis, C.A., Nanos, G.D., Kalburtji, K.L., 2007. Energy budget in organic and conventional olive groves. Agric. Eco. Environ. 122, 243-251.

Kitani, O., 1999. Energy and Biomass Engineering. CIGR, V. St Joseph, MI: ASAE.

Mikkola, H.J., Ahokas, J., 2010. Indirect energy input of agricultural machinery in bioenergy production. Renewable Energy. 35, 23-28.

Mudahar, M.S., Hignett, T.P., 1987. Energy requirements, technology and resources in fertilizer sector. Energy in Plant Nutrition and Pest Control. pp. 25-61. Amsterdam: Elsevier.

Ozpinar, S., 2002. A research on determination of agricultural structure and mechanisation characteristics of farms in Çanakkale Province. $8^{\text {th }}$ International Congress on Mechanization and Energy in Agriculture. October 15-17, pp.436-441, Kusadas1, Turkey. 2002.

Özpınar, S., 2018. An assessment of biogas production potential from animal manures in Çanakkale. COMU Journal Agriculture Faculty. 6, 109-116.

Pimentel, D., Hurd, L.E., Belloti, A.C., Forster, M.J., Oka, I.N., Sholes, O.D., Whitman, R.J., 1973. Food production and the energy crisis. Science. 182, 443-449.

Rafiee, S., Mousavi-Avval, S.H., Mohammadi, A., 2010. Modelling and sensitivity analysis of energy inputs for apple production in Iran. Energy. 35, 3301-3306.

Rallo, L., Barranco, D., Castro-Garcia, S., Connor, D.J., Gómez del Campo, M., Rallo, P., 2013. High-density olive plantations. In J. Janick (Ed.), Horticultural Reviews. 41, 303-384.

Rajaeifar, M.A., Akram, A., Ghobadian, B., Rafiee, S., Heidari, M.D., 2014. Energy-economic life cycle assessment (LCA) and greenhouse gas emissions analysis of olive oil production in Iran. Energy. 66, 139-149.

Romero-Gámez, M., Castro-Rodríguez, J., Suárez-Rey, E.M., 2017. Optimization of olive growing practices in Spain from a life cycle assessment perspective. J of Cleaner Pro. 149, 25-37.

Sánchez-Escobar, F., Coq-Huelva, D., Sanz-Cañada, J., 2018. Measurement of sustainable intensification by the integrated analysis of energy and economic flows: Case study of the olive-oil agricultural system of Estepa, Spain. J of Cleaner Pro. 463-470.

Singh, S., Mittal, J.P., 1992. Energy in production agriculture. New Delhi: Mittol Publications.

Yamane, T., 1967. Elementary Sampling Theory. New Jersey: Prentice-Hall Englewood.

Tombesi, A.M., Boco, M., Pill, M., Farinelli, D., 2002. Influence of canopy density on efficiency of trunk shaker olive mechanical harvesting. Acta Hort. 586, 291-294.

TUIK, 2018. Turkish Statistical Institute (TUIK) http://www.tuik.gov.tr/(15 September 2019). 
ÇOMÜ Zir. Fak. Derg. (COMU J. Agric. Fac.)

2020: 8 (1): 125-135

ISSN: $2147-8384$ / e-ISSN: 2564-6826

doi: 10.33202/comuagri.664249 